DOI 10.14746/ppuam.2019.9.10

\author{
Katarzyna Badźmirowska-MasŁowska
}

\title{
The Protection of Whistle-blowers within the Latest Initiatives of the Council of Europe
}

\section{Introductory Remarks}

The importance of media safety issues is a result of the media's significant role in democratic societies, which has been emphasised since the beginning of media history (from the printing press to mass audiovisual ones, to those based on information and communications technologies). Media are referred to as the "fourth estate", guardians of the public interest. They inform, educate, and provoke plural debates on crucial political, economic, socio-cultural issues, and present events having serious impact on the daily lives of people, allowing them to express different approaches and opinions and mobilise them to undertake the positive, e.g. fulfilling the public interest actions. Within their control functions, the media are obliged to scrutinize the activity of public authorities, uncover abuses of law, crimes both committed by State and non-State actors. In general, the media, as the biggest platform of performing freedom of expression and an important tool for defending other rights, are essential for democracy and are the cornerstone of the existence of the information society. Thus, their responsibility focuses on embodying the societal and individual dimension of the freedom as it is provided in Art. 10 of the European Convention on Human Rights (ECHR) ${ }^{1}$; the intrinsic connection between the individual protection of journalists or wider the safety of media staff and the guarantee of the proper realisation of media remit must be treated as a basic presumption. This dual position makes meeting the security challenges, which have been implicated by the enormous development of a new media ecosystem, more difficult. Thus, when considering the questioned issues, the implications of changes of media notion ought to be pointed out: "in the same manner as the media landscape has changed through technological convergence, the professional profile of journalists has changed over the last decade. Modern media rely increasingly on mobile and Internet-based communication

1 Convention for the Protection of Human Rights and Fundamental Freedoms, Rome, 4 XI 1950. 
services. They use information and images originating from non-journalists to a larger extent." From the subjective point of view, the term 'media' traditionally has included all media workers (e.g. freelancers) and support staff;' functional and pragmatic approach emphasis public watchdog role of media which requires to take into consideration the fact that the scope of media actors has enlarged as a result of new forms of media in the digital age. ${ }^{4}$ Hence, the notion should encompass journalists, other media professionals, those who perform public watchdog functions and even individual bloggers, all actors involved "in the production and dissemination to potentially large numbers of people of content, including information, analysis, comment and opinion." Some journalists ' protection privileges may extend to others even though they do not fully qualify as media, in particular whistle-blowers, because they can be considered as an important part of the media mission process. ${ }^{6}$ T. McGongale states that whistle-blowers working “(...) as non-journalistic actors fulfil similar functions to those of journalists or media professionals, it can be argued that they should also benefit, mutatis mutandis, from the

2 Recommendation 1950 The protection of journalists' sources adopted by the Assembly on 25 January 2011, point 11; Recommendation on a new notion of media adopted by the Committee of Ministers on 21 September 2011, point 7; Appendix to Recommendation $n$ a new notion of media adopted by the Committee of Ministers on 21 September 2011: Criteria for identifying media and guidance for a graduated and differentiated response, in particular Part 1 Media criteria and indicators - points 9-55; K. Jakubowicz, A new notion of media? Media and media-like content and activities on new communication services, Media and Information Society Division Directorate General of $\mathrm{Hu}-$ man Rights and legal Affairs, Council of Europe, Strasbourg, April 2009, pp. 17-26.

$3 \mathrm{~V}$. K. Badźmirowska-Masłowska, Status prawny a bezpieczeństwo mediów w sytuacjach wspótczesnych konfiktów „Journal of Modern Science” 2013, no. 3, p. 284; K. BadźmirowskaMasłowska, Status prawny a bezpieczeństwo mediów w sytuacjach wspótczesnych konfliktów. Wyzwania XXI wieku, in: Nie-bezpieczny świat. Systemy. Informacja. Bezpieczeństwo, eds. P. Sienkiewicz, H. Świeboda, E. Szczepaniuk, Warszawa 2015, pp. 26-41.

4 Recommendation on a new notion of media..., point 5-7; $V$. T. Mc Gonagle, How to address current threats to journalism?: The role of the Council of Europe in protecting journalists and other media actors, Expert Paper, pp. 23-27 <https://rm.coe.int/1680484e67>; K. Jakubowicz, Media revolution in Europe: ahead of the curve, Strasbourg, Council of Europe Publishing, 2011, pp. 15-20; S. Nikoltchev, T. McGonagle eds., Freedom of Expression and the Media: Standard-setting by the Council of Europe, Strasbourg 2011.

5 Recommendation on a new notion of media..., point 7 .

6 This approach is confirmed in Recommendation on the protection of journalism and safety of journalists and other media actors adopted by the Committee of Ministers on 13 April 2016 at the 1253rd meeting of the Ministers' Deputies, point 4. In practice, definitions of journalist and other media actors have been in a permanent process of change; they also can differ from country to country depending on national legislation V. Resolution No. 3 Safety of journalists, in: Political declaration and resolutions, Council of Europe Conference of Ministers responsible for media and information society, Belgrad, 7-8 November 2013, point 8; S. Parma, The Protection and Safety of Journalists: A Review of International and Regional Human Rights Law Background paper, in: Towards an effective framework of protection for the work of journalists and an end to impunity, Seminar and Inter-regional Dialogue on the protection of journalists, European Court of $\mathrm{Hu}-$ man Rights, Strasbourg, 3 November 2014. 
freedoms enjoyed by their professional counterparts". ${ }^{7}$ For that reason, the review of the latest, relevant examples of the soft law of the Council of Europe (COE) seems to be purposive, in particular in the situation when they have reflected the current reaction on an unsafe situation of whistle-blowers as well as the other initiatives devoted to their protection, including the assumptions of the proposal for a future legally-binding act which should be introduced to set up the status of the whistle-blowers. ${ }^{8}$

\section{The Protection of Whistle-Blower within the Soft Law of the Council of Europe}

A development of new information and communication technology (ICT) has caused a bourgeoning of new categories of contributors to the public debate. WikiLeaks and the Snowden Effect have elicited increased interest of whistle-blower issues, which have been at the attention of the COE since 2010.In resolution 1729(2010) and in recommendation 1916(2010) the Protection of "whistle-blowers", they were defined as "individuals who [in good faith] sound an alarm in order to stop wrongdoings that place fellow human beings at risk" and play an important role in the fight against corruption and mismanagement, both in the private and public sector, regardless of the public (e.g. the member of authorities power, armed forces, special services) or private position of the informer. ${ }^{10}$ They have often suffered because of inter alia the fear of reprisals together with the lack of relevant, protective law, adequate procedures, and the detriment of public interest in mentioned issues. Thus, the main conclusions included in the abovementioned Acts were devoted to the creation of comprehensive legal provisions at the national level (within the scope of the COE`s guidelines - see point 6.1.-6.4. of the resolution), encompassing the following legal areas: 1) media - mainly within the protection of journalistic sources ("the identity of the whistle-blower is only disclosed with his or her consent, or in order to avert serious and imminent threats to the public interest" - point 6.2.1.2.); 2) employment law - in particular in preventing unfair dismissals; 3) criminal law and procedure - with protection against criminal prosecution for defamation or the breach of secrets protected by law, and 4) specific anti-corruption measures dedicated respectively to the abovementioned sectors (point 6.1.3.). "Relevant legislation should afford bona fide whistle-blowers reliable protection against any form of retaliation (...)" (point 6.2.5; 6.2.2) and "must be accompanied by a positive evolution of the cultural attitude towards whistle-blowing" (point 7 ).

\footnotetext{
7 V. T. Mc Gonagle, op. cit., p. 24.

$8 \mathrm{~V} .<$ https://www.coe.int/en/web/cdcj/activities/protecting-whistleblowers $>$.

9 Recommendation 1916 Protection of "whistle-blowers" adopted by the Assembly on 29 April 2010.

10 Resolution 1729 Protection of "whistle-blowers" adopted by the Assembly on 29 April 2010, point 1.
} 
On 30th April 2014, the Committee of Ministers adopted the recommendation CM/ $\operatorname{Rec}(2014) 7$ on the protection of whistle-blower ${ }^{11}$, reaffirming again that freedom of expression is fundamental for the functioning of genuine democracy. Therefore, "individuals who report or disclose information [on acts and omissions in the workplace] on [serious] threats or harm to the public interest, "whistle-blowers", can contribute to strengthening transparency and democratic accountability" (preamble), as they are treated as an es-

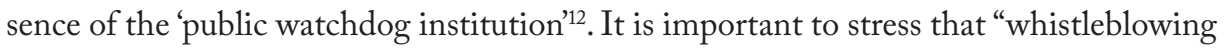
can act as an early warning to prevent damage as well as detect wrongdoing that may otherwise remain hidden". ${ }^{13}$ By the way, it is useful to make a few remarks about the contemporary blogosphere. As blogs are of different personal or 'public' character with or without specific value of a watchdog role, they need to be distinguished. D. Domingo and A. Heinonen state, "even within the range of blogs that do contribute to public debate more specific typologies can be useful to further specify the nature of their contribution to news-making, for example, the distinction between media blogs, journalist blogs, audience blogs and citizen blogs". ${ }^{14}$

The framework on the national level should be based on common principles, considering within the scope of an internal, normative, institutional and judicial system to protect those actors who can contribute to strengthening transparency and democratic accountability (preamble, item 5). For the purposes of this recommendation and in the meaning of COE standards, 'whistle-blower' is described more precisely than in the resolution $1729 / 2010$, as "any person who reports or discloses information on a threat or harm to the public interest in the context of their work-based relationship, whether it be in public or private sector" (definition - point A); it means that at the national level the definition should cover all individuals, irrespective "of the nature of their working relationship ${ }^{15}$ and whether they are paid or not" (point 3). They ought to be protected by national law, by establishing rules guaranteeing their rights and interests. They should be entitled to have the confidentiality of their identity and should be protected against retaliation of any form (directly or indirectly) as well as they ought to be subjected to: "appropriate civil, criminal or

11 Recommendation on Protection of whistleblowers adopted by the Committee of Ministers of the Council of Europe on 30 April 2014 and Explanatory Memorandum, v. declaration on the protection of journalism and safety of journalists and other media actors adopted by the Committee of Ministers on 30 April 2014.

12 Appendix to recommendation CM/Rec 2014, 7, Principles, Definitions, T. McGonagle, op. cit., p. 26.

13 Appendix to recommendation $C M / \operatorname{Rec} 2014$, point 3.

14 V. D. Domingo, A. Heinonen, Weblogs and Journalism: A Typology to Explore the Blurring Boundaries, "Nordicom Review" 2008, No. 29/1, pp. 3-15.

15 "It is the de facto working relationship of the whistleblower, rather than his or her specifc legal status (such as employee), that gives a person privileged access to knowledge about the threat or harm to the public interest". Appendix to recommendation CM/Rec 2014, 7, Explanatory Memorandum..., op. cit., point 31 . 
administrative proceedings" (point 23). Moreover, they have to be assured: "that the report or disclosure was made in accordance with the national framework" (point 23). The system should be based on a transparent, effective mechanism for acting on public interest reports and disclosures, including the periodic assessments of the effectiveness of the national framework, undertaken by the national authorities. On the other side, any prejudiced person by the reporting or disclosure of inaccurate or misleading information should retain the protection under the rules of general law (point 10).

Member States are obliged to specify the scope of the national framework. They should at a minimum include adequate provisions concerning disclosing information of public interest concerning violations of law and human rights, risks to public health, safety and to the environment. The term 'public interest' in the described context is determined at the national level. "The normative framework should reflect a comprehensive and coherent approach to facilitating public interest reporting and disclosures [of information on acts and omissions that represent a threat or harm]"; exceptions and restrictions subject to the principal of proportionality and should be in line with the rules set out in this recommendation (point 7,8).

Nota bene., the imposed restrictions under ECHR subject to legality and proportionality tests, as well as a test to whether a legitimate aim was being pursued. According to Art 10(2) any interference with the right to freedom of expression should be prescribed by law and can not be imposed for political reasons. A different scheme of rules may apply to national security, defense intelligence, public order or international relations. "The national framework should foster an environment that encourages reporting or disclosure in an open manner. Individuals should feel safe to freely raise public interest concerns" (point 12). The public reports and disclosures should be investigated promptly by relevant bodies in an efficient and effective manner. The rights of whistle-blowers ought to be subject to fair trial guarantees. Finally, the recommendation has possessed an awareness obligation of promoting the national framework in order to develop positive attitudes in society and to "facilitate the disclosure of information in cases where the public interest is at stake", by e.g. facilitating access to information and, free of charge, confidential advice for individuals contemplating making a public interest report or disclosure (point 27,28).

As the COE considered that "whistle-blower protection measures should cover all individuals who denounce wrongdoings which place fellow human beings at risk of violations of their rights protected under the ECHR"16, in 2015 the Parliamentary Assembly issued the resolution 2060(2015) and recommendation 2073(2015) Improving the protection of whistle-blowers. ${ }^{17}$ These acts are particularly devoted to the problem of improving

16 Resolution 2060 on Improving the protection of whistle-blowers adopted by the Assembly on 23 June 2015, point 8.

17 Recommendation 2073 Improving the protection of whistle-blowers adopted by the Assembly on 23 June 2015. 
the balance between the public's right to be informed and the protection of legitimate security concerns. ${ }^{18}$ The point is that whistle-blower protection measures (in particular granting asylum to those who are threatened by retaliation) ought to be extended to the persons (employees) working for national security and intelligence agencies as well as private firms working in this field (without infringing the human rights of others). The abovementioned topics have reflected and determined a range of main contemporary challenges for the protection of journalists and other media actors, including whistle-blowers. ${ }^{19}$

\section{Whistle-Blowers - Contemporary Challenges}

A very good example of problems with the relevant protection against dismissal is the case of Guja v. the Republic of Moldova ${ }^{20}$. In January 2003, the President of Moldova, within the debate on the problem of public officials placing pressure on law-enforcement bodies about pending criminal proceedings, stressed the need to fight corruption. A few days later, Mr. Guja, the journalist who has been employed as Head of the Press Department of the Prosecutor General's Office, leaked two genuine letters about pressure put on the Office by high-ranking politicians (e.g. the Vice-President of Parliament); because of his activity, the information concerning criminal law infringements, which had been perpetrated by police officers, including one, who, against former conviction, has been re-employed by the Ministry of Internal Affairs, were disclosed. Based on the abovementioned letters, the national newspaper Jurnal de Chişinău published an article. Just after publishing, Mr. Guja was dismissed by the Prosecutor General as "he had failed to consult the heads of other departments of the Office, a behaviour which constituted a breach of the press department's internal regulations." ${ }^{21}$ Before the domestic courts, the applicant, argued that: 1) the letters had not been confidential; 2) their disclosure had been dictated by good faith and 3) had been directed to counteract the trading in influence phenomena and had been in line with the Moldovan President's anti-corruption drive. His civil action seeking reinstatement was not successful, thus on 30th March 2004 he lodged an application with the European Court of Human Rights.

V. https://rm.coe.int/factsheet-on-whistleblowers-and-their-freedom-to-impart-information -ma/16807178d9>.

18 Resolution 1954 and Recommendation 2024, National security and access to information adopted by the Assembly on 2 October 2013.

19 Protection of whistleblowers: a brief guide for implementing a national framework, COE 2015.

20 Guja v. Moldova, No. 14277/04, Judgment of the European Court of Human Rights of 12 February 2008.

21 V. D. Voorhoof, Right case of Guja v. Moldova, European Court of Human Rights IRIS 2008, 6:2/1. 
In a judgement of 12th February 2008, the Court held that the dismissal had infringed the applicant's right to freedom of expression, as guaranteed by Art. 10 of ECHR. Taking into consideration both the fact that "the case concerned the pressure exerted by a high-ranking politician on pending criminal cases"22 and - as neither Moldovan legislation nor the internal regulation and prescribed procedures contained any provisions concerning the reporting of such irregularities - he had not had any alternative way for disclosure. Therefore, such an external reporting, even to a newspaper, could be justified. The Court also concluded that the national decisions constituted an interference with the applicant's right to impart information and was not necessary in a democratic society. Referring to the execution of the Court's judgement of 12th February 2008, the Government of Moldova has not accomplished its conclusion in practise. In 2009, Mr Guja lodged another complaint. In his opinion: “(...) the authorities had only simulated performance of that judgment by reinstating him in his job but had then swiftly engineered his dismissal again. [The opinion was shared by the Court who in 2018 found that]: "the Government had never intended truly to reinstate the applicant. In reality, his second dismissal had been a continued retributory measure in response to his whistleblowing of 2003. Furthermore, the domestic courts had contributed to the violation of the applicant's rights by refusing to examine his allegations and evidence, and by ignoring the principles set out in the earlier Guja case." ${ }^{23}$ The Guja v Moldova case shows in brief the basic practical problems connected with the broadness of the term 'whistle-blowers', which encompasses employees of relevant government agencies or private contractors. ${ }^{24}$ Besides, the relation between whistle-blower as a media actor and a professional journalist issue ought to be subjected to further, more detailed studies. That is because the inclusion to the certain category brings results in different legal status, ergo the differentiation in privileges, duties and the scope of protection, might occur. The problem is current due to the increasing number of attacks against media professionals' physical safety, integrity, and their property. This not only affects their freedom of expression but also the collective dimension of the right. ${ }^{25}$ Having regarded the gravity of the infringements, it must be underlined, that for the last five years the considered situation has been deteriorating.

\section{Ibidem.}

23 Press Release issued by the Registrar of the Court, ECHR 079, 2018; Guja v. Moldova, No. 1085/10, Judgment of the European Court of Human Rights of 27 February 2018, in particular points 21-22; 28-29; 41-46).

"At the time of issuing the present judgment [2018], the procedure for supervising the execution of the judgment of 12.02.2008 is still ongoing before the Committee of Ministers", the abovbementioned judgement, point 22 .

24 Notabene, it is in line with the point 9 of the resolution 2060(2015).

25 Resolution 1438 on the freedom of the press and the working conditions of journalists in conflict zones, point 2; Recommendations and resolutions adopted by the Parliamentary Assembly of the Council of Europe in the field of media and information society, point 3. 
Even in Europe, protection for journalists and other media actors operating in more and more difficult environments has been declining. ${ }^{26}$ "It is alarming and unacceptable that journalists and other media actors in Europe are increasingly being threatened, harassed, subjected to surveillance, intimidated, arbitrarily deprived of their liberty, physically attacked, tortured and even killed because of their investigative work, opinions or reporting, particularly when their work focuses on the misuse of power, corruption, human rights violations, criminal activities, terrorism and fundamentalism." ${ }^{27}$ In particular, it invokes serious concern about the grave so-called 'chilling effect' on their remit, when such 'activities' are carried out by State representatives. ${ }^{28}$ This implication has been reflected in the case of Guja $v$ Moldova. A climate of intimidation and silencing ${ }^{29}$ the actors concerned, who report on matters of public interest, leads to self-censorship, impoverishment of public debate, ergo the chilling effect may arise, which is opposite to the essence of freedom of expression, and detrimental not only to employees and civil servants but to the society as the whole. ${ }^{30}$ Moreover, the climate of attacks on and intimidation of media actors " $(. .$.$) is compounded by a culture of legal impunity for their perpetrators, [which]$ (...) is an indicator of endemic abuse of human rights." 31

According to the Court establishment, public authorities must not only refrain from interfering with the right (negative doctrine). In general, under the essence of positive obligation, the States should "ensure that everyone can exercise all of the rights en-

26 V. Reports on attacks against journalists and media freedom in Europe 2017-2019, in particular: Democracy at risk: threats and attacks against media freedom in Europe, Annual Report by the Partner Organisations to the Council of Europe Platform to Promote the Protection of Journalism and Safety of Journalists; v. Parliamentary Resolution 2035 on the Protection of the safety of journalists and of media freedom in Europe adopted by the Assembly on 29 January2015, point 5-14.

27 Recommendation CM/Rec 20164 , point 1.

28 Therefore, the following issues are considered: 1) prevention - which focuses on establishing a comprehensive legislative framework (combining civil, penal, administrative, labour etc. area of law); 2) protection - which concentrates on criminalisation violence against media staff as well as on reduction of certain risks in practise (guaranteed by the judges, prosecutors, police etc. staff) and 3) promotion of information, education and awarness-raising, combining legal, administrative and alternative measures, Appendix to Recommendation CM/Rec 2016 4, I. Guidelines.

29 Even though the civil and administrative, not criminal sanctions have been applied.

30 Recommendation of the Committee of Ministers to member States on the protection of journalism and safety of journalists and other media actors adopted by the Committee of Ministers on 13 April 2016 at the 1253rd meeting of the Ministers' Deputies; Appendix to Recommendation CM/Rec 2016 4, II. Principles, points 33-39; v. T. Baumbach, Chilling Effect as a European Court of Human Rights' Concept in Media Law Cases, "Bergen Journal of Criminal Law and Criminal Justice" 2018, Vol. 6, Issue 1, pp. 92-114.

31 Recommendation CM/Rec 20164 ., point 39.

$V$. K. Badźmirowska-Masłowska, Media a wspótczesne konfikty w świetle wybranych dokumentów Rady Europy. Wstęp do analizy prawnej, „Zeszyty Naukowe AON” 2012, vol. 3/88, pp. 257-276; K. Badźmirowska-Masłowska, Status prawny a bezpieczeństwo mediów w sytuacjach wspótczesnych konfliktów..., op. cit.; K. Badźmirowska-Masłowska, Status prawny a bezpieczensstwo mediów w sytuacjach wspótczesnych konfliktórw. Wyzwania XXI wieku..., op. cit. 
shrined in the ECHR in a practical and effective manner" 32 ; ergo they are obliged to create a favorable environment for open public debate, enabling all individuals to freely and without fear express and impart their ideas and opinions. ${ }^{33}$

This 'dual' approach is also strictly connected with the other set of problematic issues which should be mentioned. They are referring to non-legitimate political, economic, etc. influences on the freedom of expression. Hindering access to the free flow of information, caused by public authorities or powerful businesses groups, may have a negative impact not only on media security (their actors and remit) but it basically deprives citizens of their right to receive and impart information, even those which are of serious public concern (for instance issues of general interest). ${ }^{34}$ Hence, the effective system of media protection should encompass the strong protection of journalists sources of information, which constitutes a basic condition for independency and fully exercising of the media mission. ${ }^{35}$ It is important to indicate that, as a right of journalists (and wider, authorised media staff) not to disclose their sources is a professional privilege and requested the special protection, both of the journalist and anyone who provides information to him/her (a source) ${ }^{36}$ but non-journalists (e.g. individuals with their own website) cannot benefit from the right (point 15). ${ }^{37}$ Thus, the question has arisen whether the broad notion of media, including those who perform, similar to media professionals, public watchdog functions (e.g. whistle-blowers) prejudges that they are authorised to enjoy the abovementioned privilege. From the legal point of view, the answer 'yes' seems to be questionable ${ }^{38}$ but considering the dynamics of changes in the media system, due to the rapid ITC development, it cannot be unequivocally rejected.

Finally, the performing of relevant soft law from 2010-2015 has revealed an urgent problem, which seems to be crucial for further legal analyses. Infringements on the freedom of expression are considered from a human rights point of view. The COE, whose activity is precursory and traditionally based on this approach, ${ }^{39}$ has been significantly involved in initiatives counteracting them. ${ }^{40}$ The solutions concerning the whistle-blow-

32 T. McGonagle, op. cit., p. 18; Towards an effective framework of protection ...op. cit., pp. 21-22.

$33 V$. P. Leach, The principles which can be drawn from the case-law of the European Court of Human Rights relating to the protection and safety of journalists and journalism, 2013; T. Mc Gonagle, op. cit., p. 20.

34 Resolution 2179 and Recommendation 2111 on Political influence over independent media and journalists adopted by the Assembly on 29 June 2017.

35 Recommendation 1950 of the Parliamentary Assembly The protection of journalists' sources adopted by the Assembly on 25 January 2011.

$36<$ https://rm.coe.int/factsheet-on-the-protection-of-journalistic-sources-may2017/1680 $7178 \mathrm{~d} 7>$.

37 Goodwin v United Kindgdom, Voskuil v Netherlands.

38 Appendix to Recommendation CM/Rec 2011 7, points 9-55.

39 As it is provided in art. 10 of the for the Protection of Human Rights and Fundamental Freedoms.

$40 \mathrm{~V}$. K. Badźmirowska-Masłowska, Media a wspótczesne konflikty...; Declaration of the Committee of Ministers on measures to promote the respect of Article 10 of the European Convention on Human 
er's protection - as with any other new media actor-must have been established within the frame of the protection of the freedom of expression; they have been based on conclusions of debates from the end of the 20th century, concerning these issues and bearing in mind the context between governmental wrongdoing and whistleblowing. ${ }^{41}$ Due to the worrying implications of the Snowden 'case', the attempts to balance two perspectives, mass surveillance ${ }^{42}$ and the protection of whistle-blowers ${ }^{43}$, have been taken, although without full success. In particular, recommendation CM/Rec(2014)7 on the protection of whistleblowers allows the applying of information relating to national security, defence, intelligence, public order or international relations of the State: "a special scheme or rules, including modified rights and obligations" (point 5). However whistle-blowers may not be left completely without protection (e.g. asylum) or without a potential defence. ${ }^{44}$ I share the opinion that the main problem in practise is that: "whistle-blower protection laws came about through an anti-corruption agenda, not a human rights one" ${ }^{45}$; which seems to be a paradox, as whistleblowing prima facie falls under the right concerned $^{46}$, and it is confirmed in a relevant growing jurisprudence from the European Court of Human Rights under Art. 10 of the ECHR. ${ }^{47}$

\section{Concluding Remarks}

In conclusion, nowadays, regarding the protection of media issues, the Council of Europe faces a wide spectrum of old and new challenges, strictly connected with a transformation of the media ecosystem from a traditional linear paradigm to a new, proliferated

Rights of 13th January 2010.

41 See the attempt of P. Omtzigt to prepare in 2013 a Recommendation on Additional protocol to the European Convention on Human Rights on the protection of whistle-blowers who disclose governmental action violating international law and fundamental rights. W. Vandekerckhove, Freedom of expression as the "broken promise" of whistleblower protection, "La Revue des droits de l'homme" 2016, 10, points 5-9.

42 Resolution 2045 and recommendation 2067 on Mass surveillance adopted by the Assembly on 21 April 2015; W. Vandekerckhove, op. cit., point 42-55.

43 Resolution on the protection of whistleblowers..., op. cit.

$44 \mathrm{~V}$. W. Vandekerckhove, op. cit., point 7.

45 Ibidem, point 9. Additionally, the author has marked that: "even though whistleblowing policies are necessary, they are ethical only to the extent that they succeed in protecting individuality rather than institutionalizing the individual", point 57; this must be taken into serious consideration within the context of art. 9 of the Civil Law Convention on Corruption, which provisions perform so-called anti-corruption approach. On the other side, see: Global principles on national security and the right to information, "The Tshwane Principles", Tshwane 2013.

$46 \mathrm{~V}$. W. Vandekerckhove, op. cit., point 12-41.

47 V. A. Płoszka, op. cit.; <https://www.echr.coe.int/Documents/FS_Journalistic_sources_ENG. pdf $>$; $\langle$ https://rm.coe.int/factsheet-on-protection-of-sources-june2018-docx/16808b3dd9>. 
type. Redefinitions concern the scope of their term, including the broadening of the notion of journalists and other media actors. T. McGonagle says, "the transformation involves the blurring of previously distinct boundaries between production and consumption of media; professionalism and amateurism and the huge variety in types of media, media services and media content". ${ }^{48}$ Regarding the special status of whistle-blowers, it is to be said, that serious difficulties have occurred in assessing if it is of legal or practical (ethical) dimension only and whether it is considered within the freedom of expression approach, as any subject which fulfills the definition criteria of a new media actor, performing the same function as journalist. Another question has arisen, whether whistle-blowers in certain circumstances might be treated not as media actors but journalist sources. Besides, this uncertainty impacts an interpretation of a range of their duties and privileges; it also increases the scope of threats. As the new challenges for the proper protection have occurred, the comprehensive legal instrument on the protection of the whistle-blower should be considered. ${ }^{49}$ In this context, it must be pointed out that both the resolution 2060(2015) and recommendation 2073(2015) on Improving the protection of whistle-blowers has promoted launching the process of negotiating a binding legal instrument, within the described scope, covering disclosures of wrongdoings by those who are employed in the national security and intelligence area; the framework convention should be open also to non-member states (point 10.1.3. of the resolution and 3.1. of the recommendation)..$^{50}$ The complexity of current security situation, both on international and certain national levels, might seriously impede the adoption of the freedom of expression approach or even achieve a proper balance with anti-corruption regulations.

Until then, in an era of rapidly developing communication technologies, changing both the communication and safety paradigm is necessary. The main issue is to apply existing European standards and key principles to the reconfigured environment in an adequate and comprehensive manner, without their devaluation, at the national level. Furthermore, their proper implementation and execution in domestic law is the core to achieve a more effective level of whistle-blower safety. It is important to mention that after the first legal initiatives from 2010, the COE has taken a wide spectrum of activities devoted to the protection of whistle-blowers. For example, the Committee of Ministers on 19th May 2014 organized the Round Table on Safety of Journalists: From commitment to action. ${ }^{51}$ It was aimed at the following practical aspects: identifying better ways of addressing threats and violence against journalists; taking into consideration the discrete nature of a wider group of non-professionals like whistle-blowers or human rights

48 V. T. McGonagle, op. cit., p. 30.

49 The questionable issues request a wider, separate coverage.

$50 \mathrm{~V}$. Platform to promote the protection of journalism and the safety of journalists..., op. cit.

$51<$ http://www.coe.int/t/dghl/standardsetting/media/roundtable-en.asp>; <https://rm.coe.int/168049166a>. 
defenders, who communicate in the public interest; and protecting journalism effectively. It has set up guidelines on protecting all individuals who denounce wrongdoing, concerning the concept of "public interest" and has defined terms such as: openness, confidentiality, anonymity, etc. Then, in 2015 the COE set, hosted and served the technical arrangements for the Internet-based Platform to promote the protection of journalism and safety of journalism, ${ }^{52}$ via facilitating the compilation (and recording), processing and online dissemination of information on serious concerns, such as:1) personal non-verbal and verbal attacks against "journalists and other media actors, bloggers, writers, human rights defenders and other persons communicating in the public interest"53; 2) their detention and imprisonment, harassment, impunity in the mentioned cases; 3 ) threats to the confidentiality and security of journalists' sources as well as impinge on media freedom, ${ }^{54}$ causing chilling effects, (related inter alia to: judicial - e.g. defamation or political intimidation - e.g. hate speech). These criteria reflect the consistent approach of binding the personal safety of media actors with the safety of their remit. Undoubtedly, the Platform is one of the most valuable, outstanding initiative, both from the legal and practical point of view, with the perspective of world-wide cooperation in the media field; hence, the consideration of launching the whistle-blower support groups within its scope, seems to be worthwhile. ${ }^{55}$

\section{Literature}

Badźmirowska-Masłowska K., Media a wspótczesne konfikty w świetle wybranych dokumentórw Rady Europy. Wstęp do analizy prawnej, „Zeszyty Naukowe AON” 2012, No. $3 / 88$.

Badźmirowska-Masłowska K., Status prawny a bezpieczeństwo mediów w sytuacjach wspótczesnych konfliktóww, „Journal of Modern Science” 2013, no. 3.

Badźmirowska-Masłowska K., Status prawny a bezpieczeństwo mediów w sytuacjach wspótczesnych konfliktów. Wyzwania XXI wieku, in: Nie-bezpieczny świat. Systemy. Informacja. Bezpieczeństwo, eds. P. Sienkiewicz, H. Świeboda, E. Szczepaniuk, Warszawa 2015 .

$52<$ https://search.coe.int/cm/Pages/result_details.aspx?ObjectID=09000016805c5ceb >; $<$ https://www.coe.int/en/web/media-freedom/all-alerts)>; $\quad<$ https://www.coe.int/en/web/ media-freedom/the-platform $>$.

53 Ibidem. By the way, the whistle-blower as a part of a category "new media actor" is not explicite enumerated but the catalogue is not of the numerus clausus character.

54 V. M. Clark, A. Grech, Journalists Under Pressure - Unwarranted Interference, Fear and SelfCensorship in Europe, COE 2017.

55 V. W. Vandekerckhove, op. cit., point 64; also issue about implications of spreading of leaks sites, point 65 . 
Baumbach T., Chilling Effect as a European Court of Human Rights Concept in Media Law Cases, "Bergen Journal of Criminal Law and Criminal Justice", Vol. 6, Issue 1, 2018.

Clark M., Grech A., Journalists under pressure - Unwarranted interference, fear and selfcensorship in Europe, COE 2017.

Domingo D., Heinonen A., Weblogs and Journalism: A Typology to Explore the Blurring Boundaries, "Nordicom Review" 2008, No. 29/1.

Jakubowicz K., A new notion of media? Media and media-like content and activities on new communication services, Strasbourg 2009.

Jakubowicz K., Media revolution in Europe: ahead of the curve, Strasbourg 2011.

McGonagle T., How to address current threats to journalism?: The role of the Council of Europe in protecting journalists and other media actors, 2013.

Leach P., The principles which can be drawn from the case-law of the European Court of Human Rightsrelating to the protection and safety of journalists and journalism, 2013.

Nikoltchev S., McGonagle T. eds., Freedom of Expression and the Media, IRIS 2011.

Parma S., The Protection and Safety of Journalists: A Review of International and Regional Human Rights Law Background paper in: Towards an effective framework of protection for the work of journalists and an end to impunity, Strasbourg 2014.

Płoszka A., Ochrona demaskatorów (whistleblowers) w orzecznictwie ETPCZ, „Europejski Przegląd Sądowy" 2014.

Vandekerckhove W., Freedom of expression as the "broken promise" of whistleblower protection, "La Revue des droits de l'homme" 2016, No. 10.

Voorhoof D., Right case of Guja v. Moldova, IRIS 2008.

Civil Law Convention on Corruption.

Convention for the Protection of Human Rights and Fundamental Freedoms.

Declaration on the protection of journalism and safety of journalists and other media actors adopted by the Committee of Ministers on 30 April 2014.

Recommendation 1916 on the Protection of "whistle-blowers" adopted by the Assembly on 29 April 2010.

Recommendation 1950 on the protection of journalists' sources adopted by the Assembly on 25 January 2011.

Recommendation on a new notion of media adopted by the Committee of Ministers on 21 September 2011 at the 1121st meeting of the Ministers' Deputies.

Recommendation 2024 on the National security and access to information adopted by the Assembly on 2 October 2013.

Recommendation on the Protection of whistleblowers adopted by the Committee of Ministers of the Council of Europe on 30 April 2014.

Recommendation 2073 on the Improving the protection of whistle-blowers adopted by the Assembly on 23 June 2015.

Recommendation 2067on the Mass surveillance adopted by the Assembly on 21 April 2015. 
164 | Adam Mickiewicz University Law Review

Recommendation on the protection of journalism and safety of journalists and other media actors adopted by the Committee of Ministers on 13 April 2016.

Recommendation 2111 on the Political influence over independent media and journalists (Text adopted by the Assembly on 29 June 2017.

Resolution 1438 on the Freedom of the press and the working conditions of journalists in confict zones adopted by the Assembly on 28 April 2005.

Resolution 1729/2010 on the Protection of "whistle-blowers" adopted by the Assembly on 29 April 2010.

Resolution 1954 on the National security and access to information adopted by the Assembly on 2 October 2013.

Resolution on the Safety of journalists, in: Political declaration and resolutions of 2013.

Resolution 2060 Improving the protection of whistle-blowers adopted by the Assembly on 23 June 2015.

Resolution 2045 on the Mass surveillance adopted by the Assembly on 21 April 2015.

Resolution 2035 on the Protection of the safety of journalists and of media freedom in Europe adopted by the Assembly on 29 January 2015.

Resolution 2179 Political influence over independent media and journalists adopted by the Assembly on 29 June 2017.

<https://www.echr.coe.int/Documents/FS_Journalistic_sources_ENG.pdf>.

$<$ https://www.opensocietyfoundations.org/sites/default/files/tshwane-principles15-points-09182013.pdf>.

$<$ https://search.coe.int/cm/Pages/result_details.aspx?ObjectID=09000016805c5ceb>.

$<$ https://www.coe.int/en/web/media-freedom/all-alerts $>$.

$<$ https://www.coe.int/en/web/media-freedom/the-platform >.

$<$ https://www.echr.coe.int/Documents/FS_Journalistic_sources_ENG.pdf>.

$<$ https://rm.coe.int/16806fffbc .

<https://www.coe.int/en/web/media-freedom/annual-report >.

$<$ https://rm.coe.int/leaflet-safety-of-journalists-en/1680735c28>.

$<$ https://www.coe.int/en/web/media-freedom/the-platform >.

$<$ https://rm.coe.int/factsheet-on-the-protection-of-journalistic-sources-may2017/1680 $7178 \mathrm{~d} 7>$.

$<$ https://rm.coe.int/factsheet-on-whistleblowers-and-their-freedom-to-impart-information-ma/16807178d9>. 


\section{The Protection of Whistle-blowers within the Latest Initiatives of the Council of Europe}

The protection of whistle-blowers under the Article 10 of ECHR has faced a lot of complex problems, which had been a result from the implications of ICT`s development and change of the media environment. The $\mathrm{COE}$ is involved in a worldwide debate about changes taking places in a contemporary legal system in the context of the protection of human rights.

Therefore, the review of the latest legal initiatives (resolutions, recommendations, etc.) as well as other activities in the field concerned might be helpful to put the questionable issues.As the article is of the introductory character, further analysis is required. Within the human rights approach, it should concern, in particular the legal status of the whistle-blower and the issues, pertaining to legal and alternative ways of her/his protection.

Keywords: whistle-blower; approaches of protection; contemporary challenges; Council of Europe activities.

Katarzyna Badźmirowska-MasŁowska, War Studies University, Institute of Law, The International Law Department, A. Chruściela „Montera” 103, 00-910 Warszawa, Republic of Poland, e-mail: k.badzmirowskam@akademia.mil.pl 
